\title{
Enzymatic Activity of Hybrid Maize Cultivar Seeds Stored in Different Packaging Materials under Ambient Conditions with Different Seed Coatings
}

\author{
Ravindra Singh Bhadauria ${ }^{1}$, Arun Kumar Chaurasia ${ }^{2}$, Mohammad Haris Siddiqui $^{3}$, \\ Khalid Habib $^{3}$ and Soban Ahmad Faridi ${ }^{4}$ \\ ${ }^{1}$ Department of Biological Sciences, ${ }^{2}$ Department of Genetics and Plant Breeding, Sam \\ Higginbottom University of Agriculture, Technology and Sciences, \\ Prayagraj - 211 007, India \\ ${ }^{3}$ Integral Institute of Agricultural Science and Technology, Integral University, \\ Lucknow - 226 026, India \\ ${ }^{4}$ Department of Bioengineering, Faculty of Engineering, Integral University, \\ Lucknow - 226 026, India \\ *Corresponding author
}

\section{A B S T R A C T}

\section{Keywords}

Coating,Packaging material, Polymer, Biocide, Fungicide.

Article Info

Accepted:

22 August 2019

Available Online:

10 September 2019
This study was to determine the effectof seed treatment and packaging material on enzyme activities of maize seeds during ambient storage conditions. Seeds of three different varieties of maize (HQPM-1, HQPM-7 and BIO-9681) were obtained from DMR (Directorate of Maize Research), Indian Agricultural Research Institute, New Delhi. The experiment consists of treatments viz control, synthetic polymer (polyselect ${ }^{\mathrm{TM}}$ 539C Blue sparkle)@9 $\mathrm{ml} \mathrm{kg}^{-1}$, biocide (Neem oil)@10 $\mathrm{ml} \mathrm{kg}^{-1}$ and fungicide (Carbendazim) 12\% @ $2.5 \mathrm{~g} \mathrm{~kg}^{-1}$ seeds.The maize hybrid seeds were treated as per the above treatments, packed in cloth bags and plastic bags (700 gauge) and stored for 18 months respectively under ambient temperature condition. Assessment of seed germination and enzyme activities were performed with three month intervals. The results revealed that, the seed treatment with Neem oil and Carbendazim showed significant maximum germination percentage and marginal variation on enzyme activities such as amylase, peroxidase and catalase. Catalase and amylase activities increased, as germination declined, whereas, peroxidase activity decreased during storage period for all conditions, respectively. Seed germination percentage declined progressively over the period of storage more in plastic bag (approximately 29\% decline) than in cloth bag (approximately 27\% decline).

\section{Introduction}

Maize (Zea mays L.) is one of the most important cereals of the world and provides more human food than any other cereal. It has world wide significance as human food, animal feed and as good source of starch, protein, fat, oil and sucrose in addition to some of the important vitamins and minerals. Maize is one of the important cereals grain crop because of various feature like its height, genetics yield potential and productivity 
among the cereals food crops. It has one of the versatile emerging crops having wider adaptability in diverse seasons, ecologies and purposes.

It is one of the most versatile crop having wider adaptability in diverse seasons, ecologies and purposes. It is an important industrial raw material being use to produce more than 3000 product using maize directly or indirectly. Proper seed treatment is needed to maintain the seed quality during storage. Good storage conditions can reduce deterioration of seed. Seed moisture content, relative humidity and during storage are responsible for the main effect on seed quality. It seed coatings with natural or synthetic polymers have gained rapid acceptance by the seed industry as a much safer coating material. The storability of poly coated seeds has also to be investigated in order to determine the viability of seeds for long term. Proper storage conditions are important for maintaining valuable seeds. Seed viability and vigour are highest at the time of physiological maturity thereafter the seed gradually declines in viability and vigour. Physiological and Biochemical aspects of fruit and seed development in large seeded legumes have been intensively studied, leading to comprehend the major events of seed formation and maturation ${ }^{1}$.

The descriptive use of chemicals and their residual toxicity adversely affect the seed quality because they are not readily degradable physically or biologically. Hence the safe and feasible approach of seed treatment is required which are economical, eco-friendly and non-harmful to animal and human being.

In order to prevent the qualitative losses due to several Biotic and abiotic factor during storage and several methods are being adopted such as seed treatment with chemical, fungicides, polymer coating, polymer dyes and storing in safe container such as cloth bag, jute bag, polythene bag and HDPE bag (High Density Polythene) besides sanitation of the storage places.

Seed deterioration starts even in optimum storage conditions. Genetic and environmental modifications influences seed deterioration at harvest and proceeds in storage ${ }^{2}$. The ability of seeds to produce antioxidative enzymes considerably differ depending on species and genotype and enzymatic detoxification and repair of cell membranes are the main means to delay ageing ${ }^{3}$.

Demonstrated that early deteriorative changes in seeds under storage was due to various Biochemical processes viz., denaturation of Biomolecules and accumulation of toxic substances in addition to loss of membrane integrity.

During deterioration, marked changes in the content and activity of certain respiratory enzymes such as catalase, peroxidase, dehydrogenase, cytochrome oxidase and glutamic acid decarboxylase were noticed with decline in viability. Several authors have emphasized that the main factors responsible for the conservation of seeds during storage are the temperature and the moisture content of the seeds.

In the storage conditions, temperature and relative humidity are key factors in maintaining seed quality ${ }^{4}$, influencing the speed of the Biochemical processes and indirectly interfering in water content of seeds. Changes in physiology of the seeds are indirectly related to the integrity of their cell membranes 5 , which, in turn, depend on the nature of the enzymes and structural proteins of each species. The enzymes have been used in the assessment of physiological and Biochemical changes in stored seeds ${ }^{6}$. 


\section{Materials and Methods}

\section{Source of seed}

The hybrid seeds of maize varieties were obtained from DMR (Directorate of Maize Research), Indian Agricultural Research Institute, New Delhi. The seeds of Maize varieties treated with Biocide (Neem oil), Polymer and fungicide (Carbendazim) and different packaging material such as plastic bag and cloth bag, stored under ambient temperature condition. Experiment was carried out for 18 months with interval of 3, 6 , $9,12,15,18$ months respectively at Advanced centre for Bioengineering and Bioinformatics, Integral Information\& Research Centre, Integral University.

\section{Varieties}

V1: Hybrid maize (HQ PM-1)

V2:Hybrid maize (HQ PM-7)

V3:Hybrid maize (Bio-9681)

\section{Seed treatment details}

T0: Control (untreated)

T1: Seed treatment with Neem oil @ $10 \mathrm{ml} / \mathrm{kg}$ of seeds

T2: Seed treatment with Polymer Coating @ 9 $\mathrm{ml} / \mathrm{kg}$ of seeds

T3: Seed treatment with Carbendazim 12\%@ $2.5 \mathrm{~g} / \mathrm{kg}$ of seed

\section{Packaging material}

C1: Plastic Bag (700 gauge)

C2:Cloth Bag (as per seed certification standard)

\section{Temperature}

Ambient temperature storage conditions

\section{Germination percent (\%)}

Germination test was conducted in four replications, each with 100 seeds by adopting between paper method as prescribed by ISTA $^{7}$. A temperature of $25 \pm 5^{\circ} \mathrm{C}$ and relative humidity of 90 per cent was maintained during germination test. The germination counts were made on seventh day of germination test, respectively for normal seedlings and the germination was expressed in percentage.

$G P=\frac{\text { No. of normal seedling } \times 100}{\text { Total seeds used for germination }}$

\section{Enzyme activity}

\section{Determination of Catalase activity}

Catalase activity was obtained by Chance's and Maehly Method (1955) ${ }^{8}$. 5mlof solution containing $300 \mu \mathrm{M}$ phosphate buffer $(\mathrm{pH}=$ 6.8) and $100 \mu \mathrm{m}$ hydrogen peroxide $\left(\mathrm{H}_{2} \mathrm{O}_{2}\right)$ was prepared and $1 \mathrm{ml}$ of enzyme extraction ( 2 times diluted) added and left at $25^{\circ} \mathrm{C}$ for $1 \mathrm{~min}$. Then $10 \mathrm{ml}$ sulfuric acid $(2 \%)$ was added and titrated with potassium permanganate $(0.01 \mathrm{~N})$ till pink color was achieved.

\section{Determination of peroxidase activity}

Activity of peroxidase was determined with Chance's and Maehly Method $(1955)^{8}$. One gram of fresh organ were grinded with $4 \mathrm{ml}$ of extraction solution, containing $1.2 \mathrm{~g}$ tris, $2 \mathrm{~g}$ ascorbic acid, $3.8 \mathrm{~g}$ borax, 2 g EDTA$\mathrm{Na}_{2}, 50$ g polyethyleneglycol 2000 in 100 $\mathrm{ml}$ distilled water. The solution was left at $4^{\circ} \mathrm{C}$ temperature for $24 \mathrm{~h}$. Then it was centrifuged at $400 \mathrm{~g}$ for $30 \mathrm{~min}$. Added 0.1 $\mathrm{ml}$ of enzyme extract to a mixture of $1 \mathrm{ml}$ acetate tampon solution $(0.2 \mathrm{M}, \mathrm{pH}=5), 0.4$ 
$\mathrm{ml}$ hydrogen peroxidase (3\%) and 0.2 mlbenzydin:alcohol (0.01 $\mathrm{M})$. Then the absorbance on $530 \mathrm{~nm}$ wavelength was observed. The enzyme activity was calculated.

\section{Determination of $\alpha$-amylaseactivity}

$100 \mu \mathrm{l}$ of $20 \mathrm{mM}$ phosphate buffer $\mathrm{pH} 6.9$, containing $\alpha$-amylase at a concentration of 0.5 $\mathrm{mg} / \mathrm{ml}$ were incubated at $25^{\circ} \mathrm{C}$ for $10 \mathrm{~min}$. After pre-incubation, $500 \mu \mathrm{l}$ of $0.5 \%$ starch solution (20 mM phosphate buffer, $\mathrm{pH}$ 6.9) was added. The reaction mixtures were then incubated at $25^{\circ} \mathrm{C}$ for $10 \mathrm{~min}$. The reaction was stopped with $1 \mathrm{ml}$ of 3,5dinitrosalicylic acid (DNS) color reagent ${ }^{9}$. Then incubated in a boiling water bath for $5 \mathrm{~min}$ and cooled to room temp. Absorbance (A) was measured at 540nm. Experiment was laid out in completely randomized design with factorial concept in four replications. The seed samples drawn at after three months intervals of storage and evaluated for various seed quality parameters in order to determine the suitable treatment for better storage.

\section{Results and Discussion}

\section{Germination}

The results of the present investigation was the effect of use of various seed treatments such as Biocide (Neem oil), Polymer and fungicide (Carbendazim) months and the effect of different packaging materials such as plastic and cloth bag on the enzyme activity which was responsible for maintenance of seed quality, longevity and accelerated ageing of hybridmaize varieties HQPM-1,HQPM-7 and BIO-9681 on storage during 0,3,6,9,12,15 and 18 months respectively.

Seed germination (\%) was declined progressively over a period of storage due to enzyme activity with packaging materials and seed coating polymers and chemicals. Among packaging materials, seeds stored in cloth bag recorded highest germination $(81.1 \%)$ and to lowest $(78.4 \%)$ in plastic bag at eighteenth month of storage as against the initial seed germination of 97.6 per cent. With respect to the treatments, Neem Oil @ 10ml/kg of seeds recorded significantly highest germination (84.0\%) and lowest (69.9\%) was in control (T0) at eighteenth month of storage (Fig 1).After storage of 18 months variety HQPM1 showed higher germination percentage. Similar finding was also obtained in cowpea ${ }^{10}$ andin soybean $^{11}$.

\section{Enzymatic activity}

Results obtained on $\alpha$-amylase activity as influenced by different packaging and storage conditions. No significant differences were observed up to 12 months of storage whereas after 12 months, there was significant increase in $\alpha$-amylase activity at all the condition of storage. Control seed recorded significantly higher values of $\alpha$-amylase activity over all other treatments, while in plastic bags (C1) significantly higher $\alpha$-amylase activity was observed compared to cloth bag(C2). In Carbendazim 12\%@2.5 g/kg and Neem Oil @ $10 \mathrm{ml} / \mathrm{kg}$ show lowest $\alpha$-amylase activity on the other hand the highest was in control (T0).

The result showed that the activity of $\alpha$ amylase constant up to 12 months and increased thereafter. Amongst the three hybrid HQPM-1showed significantly higher $\alpha \alpha$ amylase activity whereas hybrid B10-9681 showed reduction after 15 month as compared to control.

In storage period, $\alpha$-amylase activity was found in increasing trends whereas germination percentage showed decreasing trends. $\alpha$-Amylase has an active role in the hydrolysis of the starch during seed germination. The $\alpha$-amylase activity was 
enhanced by prolonged darkness ${ }^{12}$, leaf infection with virus ${ }^{13}$, heat stress ${ }^{14}$ and water stress $^{15}$. The above results suggested that the $\alpha$-amylases were involved in the growth regulation as well as in stress resistance. Similar observations were also reported by Chauhan in wheat seeds ${ }^{16}$.

In cereal seeds, the development of $\alpha$-amylase activity constitutes an important event in germination. During germination of seeds, a massive breakdown of the reserve substances begins with the help of amylolytic, proteolytic and lipolytic enzymes and the products are transported to the growing seedlings for their development. The remaining small amount of protein represents enzymes concerned in metabolic processes during seed development and germination.

The results of catalase activity presented in fig3revealed significant differences between storage containers from 10 months of storage and up to 18 months of storage period. No significant differences were observed up to 8 months of storage. Yin et al., also suggested decreasing trends in catalase activity with decreasing percentage of germination ${ }^{17}$.

There was variation in result observed in maize varieties HQPM1 shows gradual increase in Catalase activity while in maize varieties HQPM 7 and Bio-9681 shows reduction in Catalase activity.

The increase in catalase activity has been related to the production of $\mathrm{H}_{2} \mathrm{O}_{2}$ in conditions of oxidative stress ${ }^{18}$. Yin et al., have observed in artificially aged rice seeds of Oryza sativa L. cv. a decreased catalase activity, resulting in a drop in the percentage of germination $^{17}$.

Similar results were found by Chauhan, where the decrease of the activities of catalase and peroxidase in Triticum aestivum seeds during aging have resulted in lower viability and vigor $^{16}$. Decreasing trends in catalase activity was observed in cloth bags (C2) as compared to plastic bags (C1).

Among the seed treatment Carbendazim 12\%@2.5 g/kg and Neem@10ml/kg shows similar Catalase activity when compared to control (T0).

Low reduction of peroxidase activity was observed in cloth bag (C1) compared to control (T0). Among the seed treatment Carbendazim 12\%@2.5 g/kg and Neem oil @ $10 \mathrm{ml} / \mathrm{kg}$ shows similar peroxidise activity when compared to control (T0).

Peroxides activity decreases substantially with ageing, due to which seeds become more sensitive to the effects of oxygen and free radicals in membrane unsaturated fatty acids and produce lipid peroxidation products such as MDA and lipid conjugants.

Similar results were observed in radish ${ }^{19}$ and in sunflower ${ }^{20}$.Chauhan studied the level of various enzymes, and found the reason to be, seed deterioration under natural ageing, which results in decrease in enzyme activity in seeds, thus, lowering its respiratory potential, which in turn lowers both the energy (ATP) and food supply to the germinating seed ${ }^{16}$.

Several changes in the enzyme macromolecular structure may contribute to their lower effectiveness. They may undergo compositional changes by losing or gaining certain functional groups, by oxidation of sulfhydral groups or by conversion of amino acids within the protein structure.

The Neem oil @ $10 \mathrm{ml}$ per kg of seed recorded significantly higher values for germination, indicating the superiority, over control and other treatments in maintaining the seed quality in storage. 
Table.1 Effect of seed treatment and packaging material on germination $\%$ during storage in maize

\begin{tabular}{|c|c|c|c|c|c|c|c|c|c|c|c|}
\hline \multirow[t]{4}{*}{$\begin{array}{l}\text { S. } \\
\text { No. }\end{array}$} & \multirow[t]{4}{*}{ Crop } & \multirow[t]{4}{*}{ Variety } & \multirow[t]{4}{*}{$\begin{array}{l}\text { Variety } \\
\text { Code }\end{array}$} & \multirow[t]{4}{*}{ Combination } & \multicolumn{7}{|c|}{$\begin{array}{c}\text { Germination\% (Seed Stored in Plastic bag \& } \\
\text { Cloth Bag) }\end{array}$} \\
\hline & & & & & \multicolumn{7}{|c|}{$\mathrm{C}_{1}-$ Plastic bag and $\mathrm{C}_{2}-$ Cloth bag } \\
\hline & & & & & \multicolumn{7}{|c|}{ Duration (Months) } \\
\hline & & & & & 0 & 3 & 6 & 9 & 12 & 15 & 18 \\
\hline \multirow[t]{4}{*}{1} & \multirow[t]{4}{*}{ Maize } & \multirow[t]{4}{*}{ HQPM-1 } & \multirow[t]{4}{*}{ V1 } & $\mathrm{V}_{1} \mathrm{~T}_{0} \mathrm{C}_{1}($ Control $)$ & 58.5 & 57.5 & 56 & 54.5 & 50 & 39.5 & 30.6 \\
\hline & & & & $\mathrm{V}_{1} \mathrm{~T}_{1} \mathrm{C}_{1}(\mathrm{Neem})$ & 78.5 & 77.5 & 76.5 & 74.5 & 70 & 60 & 50 \\
\hline & & & & $\mathrm{V}_{1} \mathrm{~T}_{2} \mathrm{C}_{1}$ (Polymer) & 62.5 & 61.25 & 60 & 58 & 54.5 & 43.5 & 34 \\
\hline & & & & $\begin{array}{lcl}\mathrm{V}_{1} & \mathrm{~T}_{3} & \mathrm{C}_{1} \\
\text { (Carbendazim) }\end{array}$ & 66.5 & 65.5 & 64 & 62.5 & 58.5 & 48 & 38 \\
\hline \multirow[t]{4}{*}{2} & Maize & HQPM-7 & V2 & $\mathrm{V}_{2} \mathrm{~T}_{0} \mathrm{C}_{1}($ Control $)$ & 58.25 & 57 & 55.5 & 53.5 & 49.5 & 38.5 & 29.5 \\
\hline & & & & $\mathrm{V}_{2} \mathrm{~T}_{1} \mathrm{C}_{1}(\mathrm{Neem})$ & 78.25 & 77.25 & 76.25 & 74.25 & 69.75 & 59.75 & 49.75 \\
\hline & & & & $\mathrm{V}_{2} \mathrm{~T}_{2} \mathrm{C}_{1}$ (Polymer) & 62 & 61 & 59 & 57 & 54 & 42.5 & 33 \\
\hline & & & & $\begin{array}{lcl}\mathrm{V}_{2} & \mathrm{~T}_{3} & \mathrm{C}_{1} \\
\text { (Carbendazim) }\end{array}$ & 66 & 65 & 6 & 61.5 & 57.5 & 46.5 & 37.5 \\
\hline \multirow[t]{4}{*}{3} & Maize & Bio-9681 & V3 & $\mathrm{V}_{3} \mathrm{~T}_{0} \mathrm{C}_{1}$ (Control) & 58 & 56.5 & 54.5 & 52 & 49 & 37.5 & 29 \\
\hline & & & & $\mathrm{V}_{3} \mathrm{~T}_{1} \mathrm{C}_{1}(\mathrm{Neem})$ & 78 & 77 & 76 & 94 & 69 & 59.5 & 49.5 \\
\hline & & & & $\mathrm{V}_{3} \mathrm{~T}_{2} \mathrm{C}_{1}$ (Polymer) & 61.5 & 60.75 & 58 & 56 & 53 & 41.5 & 32 \\
\hline & & & & $\begin{array}{lcl}\mathrm{V}_{3} & \mathrm{~T}_{3} & \mathrm{C}_{1} \\
\text { (Carbendazim) } & \end{array}$ & 65.5 & 64.5 & 62 & 61 & 56 & 46 & 37 \\
\hline \multirow[t]{4}{*}{4} & Maize & HQPM-1 & V1 & $\mathrm{V}_{1} \mathrm{~T}_{0} \mathrm{C}_{2}($ Control $)$ & 58.5 & 57.5 & 56 & 54.5 & 50 & 39.5 & 30.6 \\
\hline & & & & $\mathrm{V}_{1} \mathrm{~T}_{1} \mathrm{C}_{2}($ Neem$)$ & 81 & 80 & 79 & 77 & 73 & 61.25 & 51.5 \\
\hline & & & & $\mathrm{V}_{1} \mathrm{~T}_{2} \mathrm{C}_{2}$ (Polymer) & 64 & 63 & 62 & 60 & 56 & 46 & 36 \\
\hline & & & & $\begin{array}{lcl}\mathrm{V}_{1} & \mathrm{~T}_{3} & \mathrm{C}_{2} \\
\text { (Carbendazim) }\end{array}$ & 69.5 & 68.5 & 67.5 & 65.5 & 61.5 & 54 & 44 \\
\hline \multirow[t]{4}{*}{5} & Maize & HQPM-7 & V2 & $\mathrm{V}_{2} \mathrm{~T}_{0} \mathrm{C}_{2}$ (Control) & 58.25 & 57 & 55.5 & 53.5 & 49.5 & 38.5 & 29.5 \\
\hline & & & & $\mathrm{V}_{2} \mathrm{~T}_{1} \mathrm{C}_{2}(\mathrm{Neem})$ & 79 & 78 & 77 & 75 & 71 & 61 & 51 \\
\hline & & & & $\mathrm{V}_{2} \mathrm{~T}_{2} \mathrm{C}_{2}$ (Polymer) & 63 & 62 & 61 & 59 & 55 & 45 & 35 \\
\hline & & & & $\begin{array}{lcc}\mathrm{V}_{2} & \mathrm{~T}_{3} & \mathrm{C}_{2} \\
\text { (Carbendazim) } & \end{array}$ & 68 & 67 & 66 & 64 & 60 & 52.5 & 42.5 \\
\hline \multirow[t]{4}{*}{6} & Maize & BIO-9681 & V3 & $\mathrm{V}_{3} \mathrm{~T}_{0} \mathrm{C}_{2}$ (Control) & 58 & 56.5 & 54.5 & 52 & 49 & 37.5 & 29 \\
\hline & & & & $\mathrm{V}_{3} \mathrm{~T}_{1} \mathrm{C}_{2}(\mathrm{Neem})$ & 78.75 & 77.75 & 76.75 & 74.75 & 70.25 & 60.25 & 79 \\
\hline & & & & $\mathrm{V}_{3} \mathrm{~T}_{2} \mathrm{C}_{2}$ (Polymer) & 62.75 & 61.75 & 60.5 & 58.75 & 54.75 & 44.5 & 34.5 \\
\hline & & & & $\begin{array}{lcl}\mathrm{V}_{3} & \mathrm{~T}_{3} & \mathrm{C}_{2} \\
\text { (Carbendazim) } & \end{array}$ & 67 & 66 & 65 & 63 & 59 & 49 & 39 \\
\hline
\end{tabular}


Fig.1Effect of seed treatmentand packaging material on germination \% during storage in maize a)HQPM-1 c) HQPM-7 e) Bio-9681 with plastic bagb) HQPM-1 d) HQPM-7 f) Bio-9681 with cloth bag

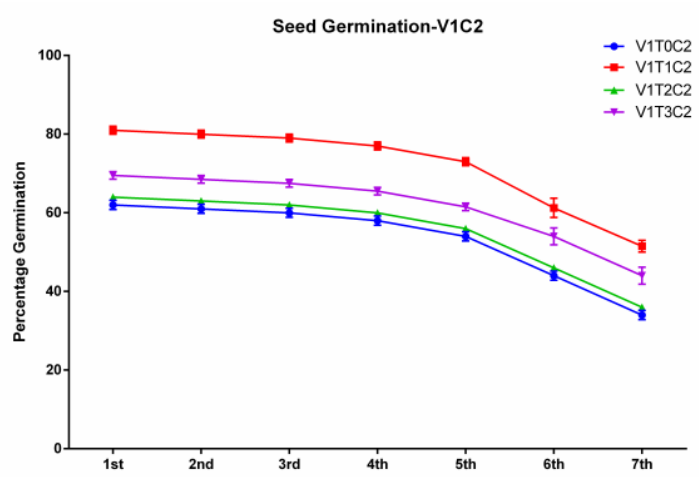

a)

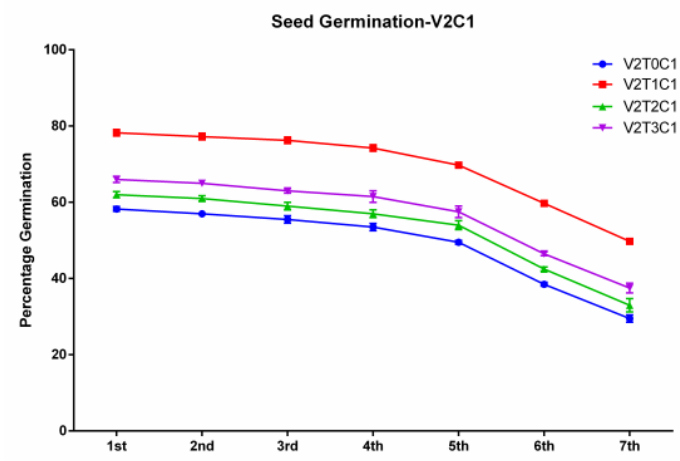

c)

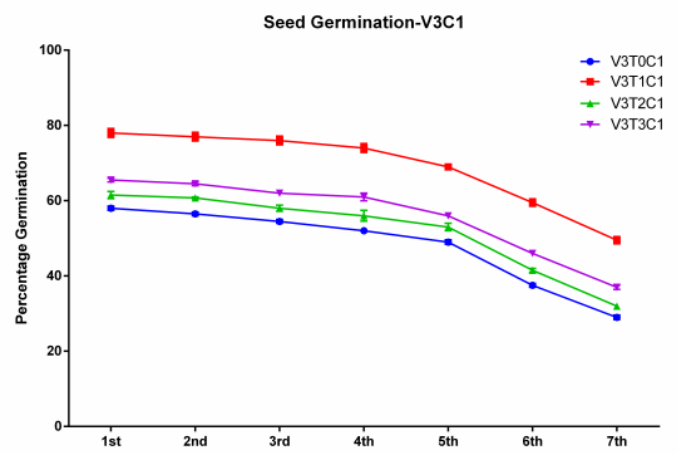

e)

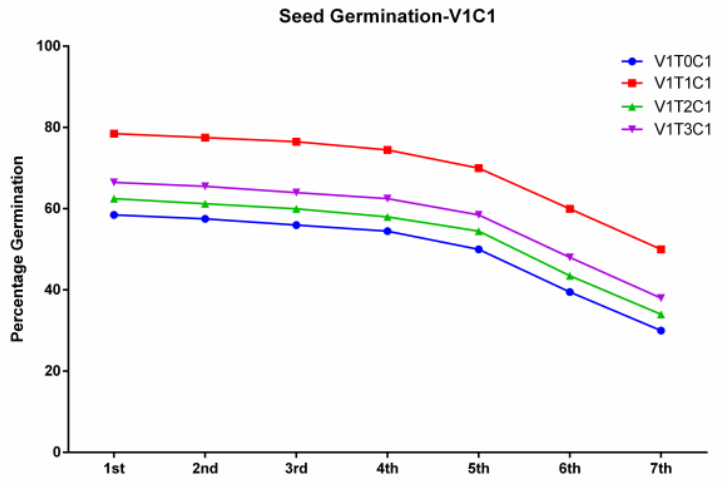

b)

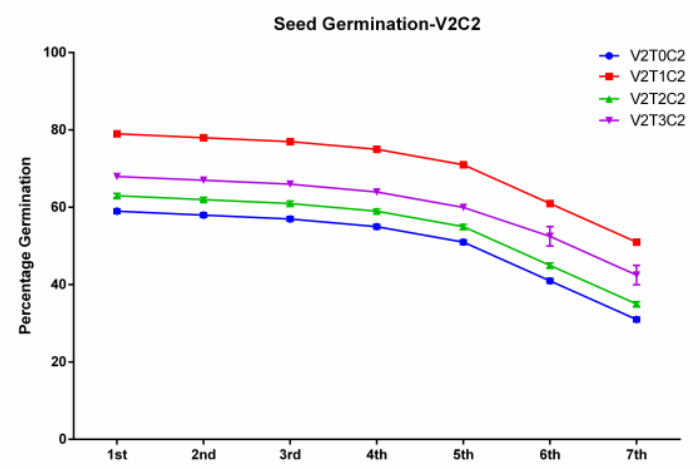

d)

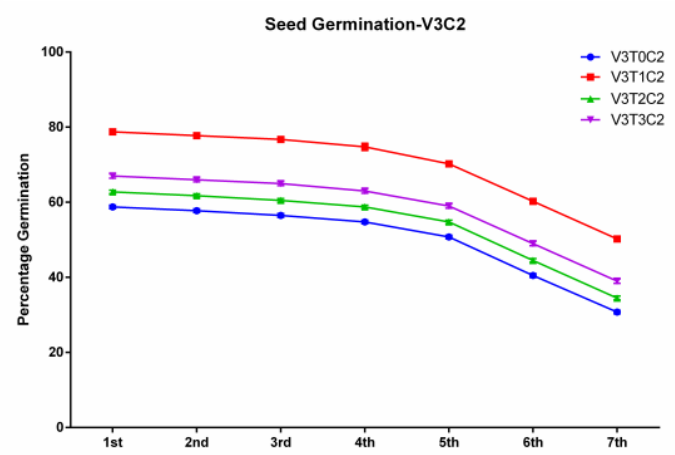

f) 
Fig.2 Effect of seed treatmentand packaging material on $\alpha$-amylase activity during storage in maizea) HQPM-1 c) HQPM-7 e) Bio-9681 with plastic bagb) HQPM-1 d) HQPM-7 f) Bio-9681 with cloth bag

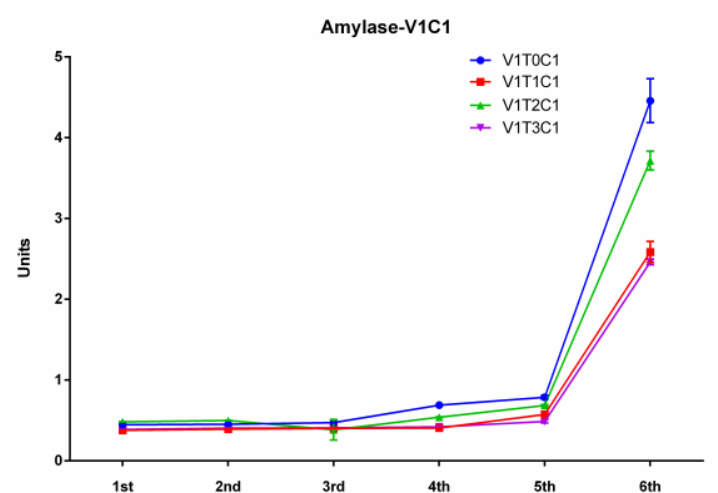

a)

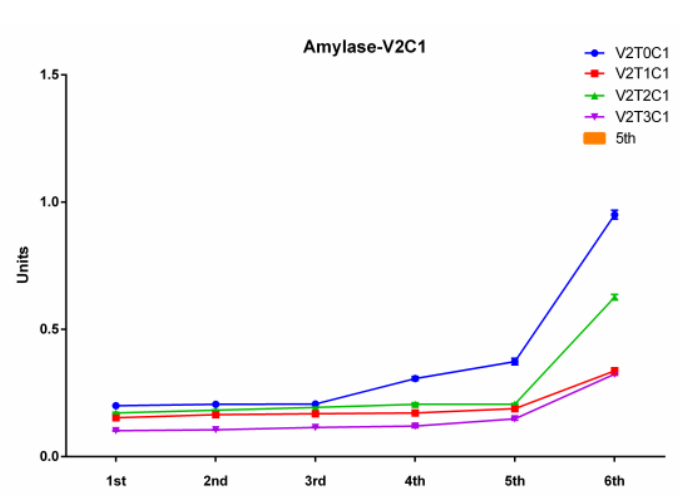

c)

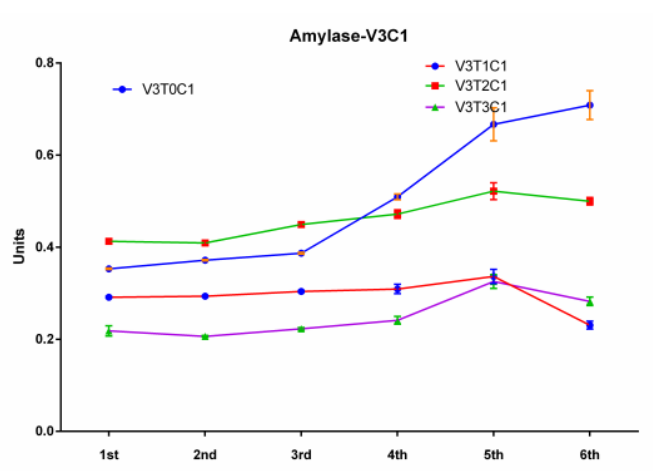

e)

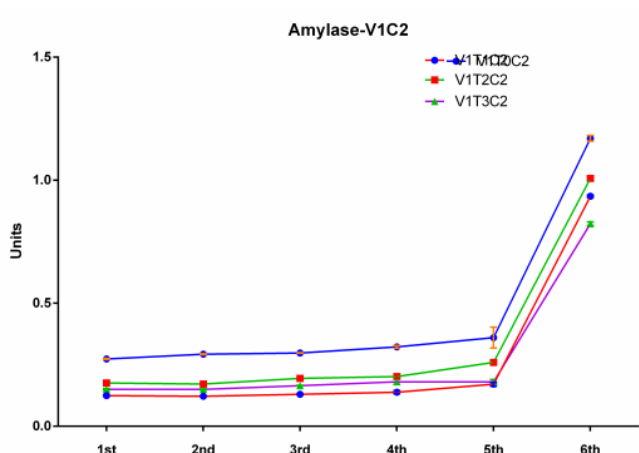

b)

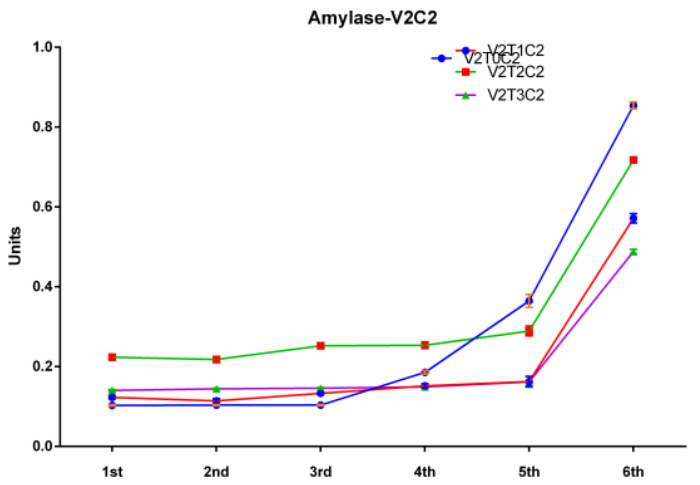

d)

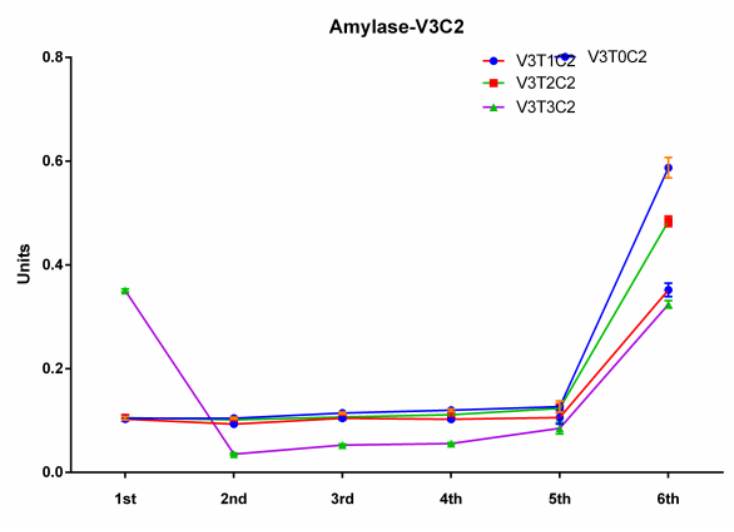

f) 
Fig.3 Effect of seed treatmentand packaging material on catalase activity during storage in maizea) HQPM-1 c) HQPM-7 e) Bio-9681 with plastic bagb) HQPM-1 d) HQPM-7 f) Bio-9681 with cloth bag

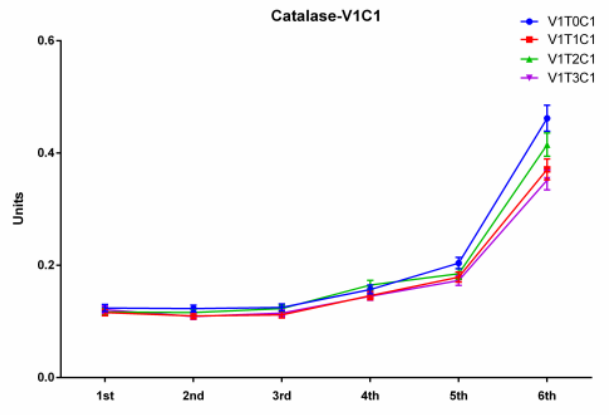

a)

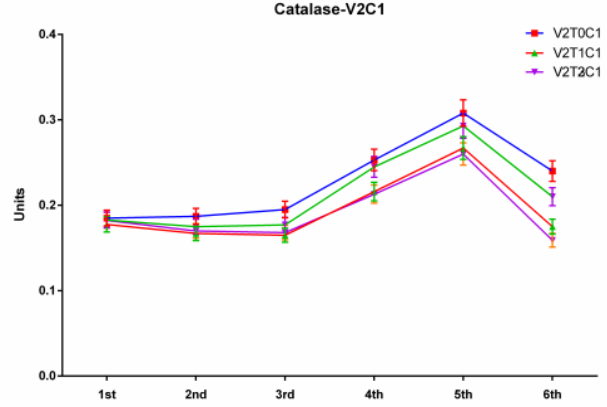

c)

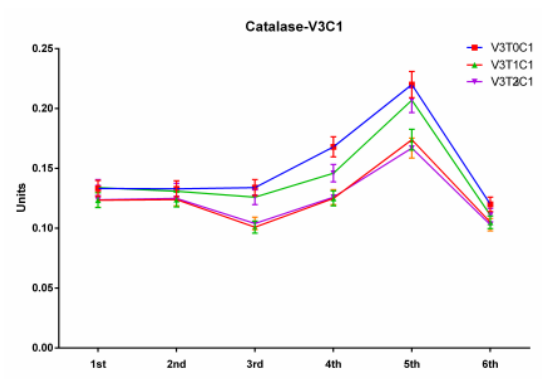

e)

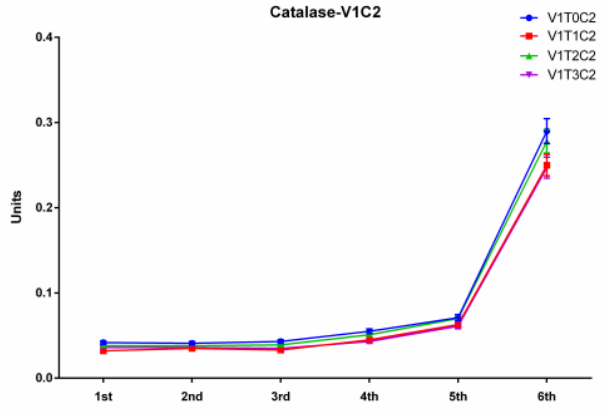

b)

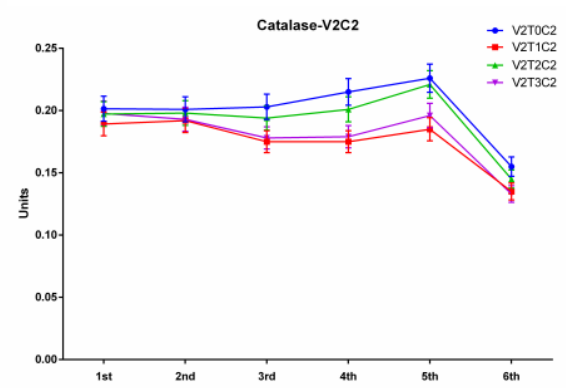

d)

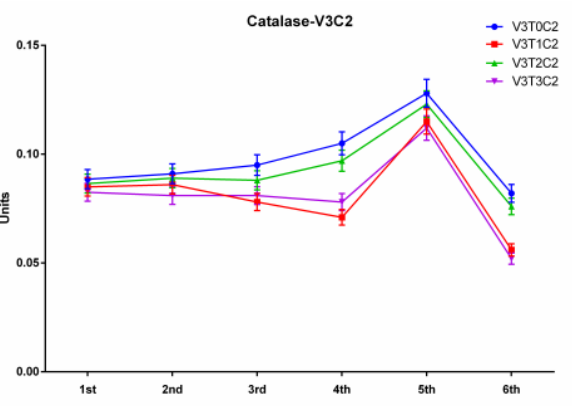

f) 
Fig.4 Effect of seed treatment and packaging material on peroxidase activity during storage in maizea) HQPM-1 c) HQPM-7 e) Bio-9681 with plastic bagb) HQPM-1 d) HQPM-7 f) Bio-9681 with cloth bag

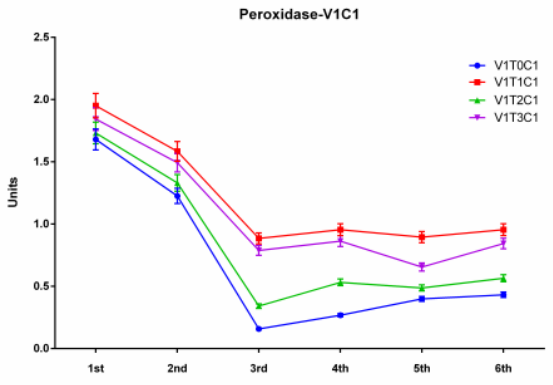

a)

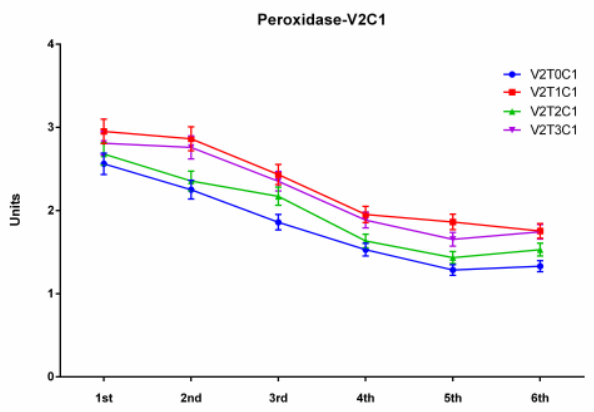

c)

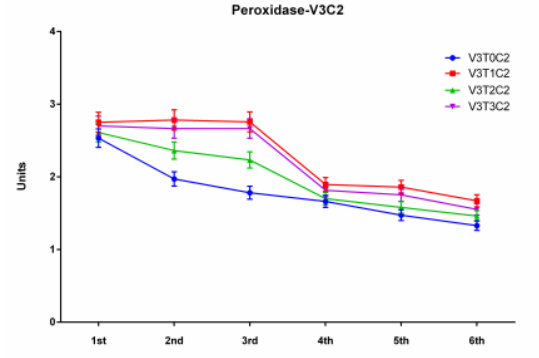

e)

Among the two packing material i.e. Plastic bag (700 gauge) and Cloth bag (as per seed certification standards), Seed ageing and deterioration of seed are irreversible, inexorable and inevitable process, but the rate of seed deterioration could be slowed either by storing the seeds under controlled condition or by imposing seed treatment with polymer coating along with seed treatment chemicals ${ }^{21}$. As the controlled condition involves the huge cost, the seed treatment remains the best alternative approach to maintain the seed quality. Similar findings were also observed by Kaushik and Rai ${ }^{22}$.

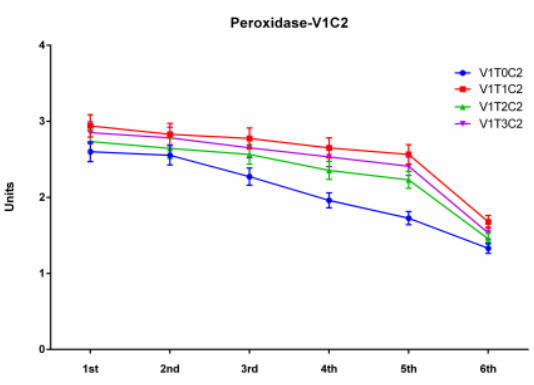

b)

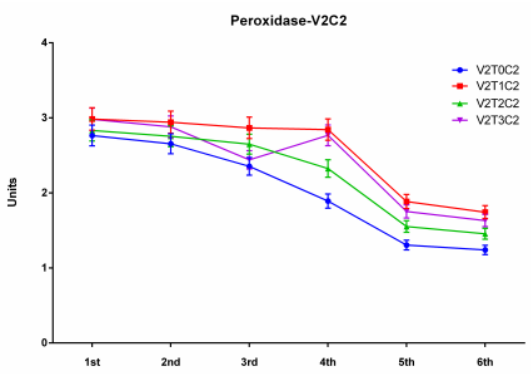

d)

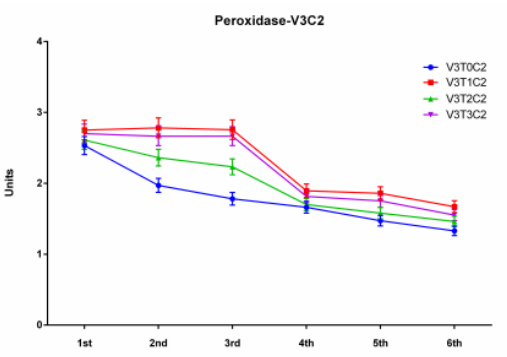

f)

It is concluded that from the present investigation of seeds treated with Neem oil @ $10 \mathrm{ml}$ per $\mathrm{kg}$ of seed and cloth bag show significantly higher seed quality parameters. After storage of 18 months, variety HQPM-1 showed higher germination percentage, which was recorded in seeds treated with Biocide (Neem oil) which was stored in cloth bag $(51.50 \%)$ respectively and lowest in variety Bio-9681 stored in plastic bag of control (29\%), at the end of storage. The rate of reduction in germination percentage from the beginning of the storage period till the end of $18^{\mathrm{th}}$ month of storage was observed lesser in 
seeds packed in cloth bagand Seeds treated with Biocides (Neem oil) in comparison with other treatments and exhibited superiority in maintaining the seed quality throughout the storage period. The seeds treated with Neem oil @ $10 \mathrm{ml}$ per $\mathrm{kg}$ of seed showed significantly higher seed quality parameters than the seeds treated with polymer @ $9 \mathrm{ml}$ per kg of seed and Carbendazim 12\%@2.5 g per $\mathrm{Kg}$.

Research findings reveal that seed quality parameters declined progressively with the increase in storage period. Germination percentage declined with an increase in $\alpha$ amylase and catalase enzyme activities but peroxidase activity declined throughout the process. Seed treatment with Biocide and packaging in cloth bag were found to be more effective, extending seed longevity, safe from deterioration and maintaining seed quality during storage. Seed ageing and deterioration of seed can be slowed down by storing the seeds under controlled condition or by imposing seed with Biocide coating along with cloth bag packaging and it was a natural and cost effective treatment for maintenance of seed quality by increasing the percentage of germination.

\section{Acknowledgement}

This is to acknowledge Sam Higginbottom University of Agriculture, Technology and Sciences, Prayagraj and Integral University, Lucknow for providing the facilities to carry out the present research work. Integral University, Lucknow is also acknowledged in the present work for providing a manuscript communication number IU/R\&D/2019MCN000693.

\section{References}

Rafique N, Raza SH, Qasim M, Iqbal N. Presowing application of ascorbic acid and salicylic acid to seed of pumpkin and seedling response to salt. Pak J Bot 2011; 43: 2677-2682.

Bewley JD, Black M. Seeds. In: Seeds. Springer, 1994, pp 1-33.

Tavakol AR, Ghasem F, Majnoun HN, Alizadeh H, Bihamta MR. Some effects of seed aging on germination characteristics and activities of catalase and peroxidase antioxidant enzymes in Barley genotypes (Hordeum vulgare). Iran J Agric Sci 2007; 38-1: 337-346.

Tonin GA, Perez SCJG de. Physiological quality of Ocotea porosa (Ness et Martius ex Ness) seeds after different storage and sowing conditions. Rev Bras Sementes 2006; 28: 26-33.

Carvalho LF de, Sediyama CS, Reis MS, Dias DCFS, Moreira MA. Influence of soaking temperature of soybean seeds in the eletric conductivity test to evaluate physiological quality. Rev Bras Sementes 2009; 31: 9-17.

Santos CMR, Menezes NL de, Villela FA. Physiologic and biochemical alterations in artificially aged bean seeds. Rev Bras Sementes 2004; 26: 110-119.

Ista. International rules for seed testing (edition 2008). Int. rules seed testing. Zurich, Switzerland. 2008. doi:10.15258/istarules.2015.F.

Chance B, Maehly AC. Assay of catalases and peroxidases. Methods Enzym 1955; 2: 764-775.

Bernfeld P. Amylase $\beta$ and $\alpha$ (Assay Method), in methods in enzymology I, Colowick and Kaplan, Ed. 1955.

Hunje R V, Kulkarni GN, Shashidhara SD, Vyakaranahal BS. Effect of insecticide and fungicide treatment on cowpea seed quality. Seed Res 1990; 18: 9092.

Gupta A, Aneja KR. Seed deterioration in soybean varieties during storagephysiological attributes. Seed Res 2004; 32: 26-32. 
Saeed M, Duke SH. Amylases in pea tissues with reduced chloroplast density and/or function. Plant Physiol 1990; 94: 1813-1819.

Heitz T, Geoffroy P, Fritig B, Legrand M. Two apoplastic $\alpha$-amylases are induced in tobacco by virus infection. Plant Physiol 1991; 97: 651-656.

Commuri PD, Duke SH. Apoplastic $\alpha$-amylase in pea is enhanced by heat stress. Plant cell Physiol 1997; 38: 625-630.

Ashraf MY, Azmi AR, Naqvi SSM, Khan AH. Alpha amylase, protease activities and associated changes under water stress conditions in wheat seedling. Pakistan J Sci Ind Res 1995.

Chauhan DS, Deswal DP, Dahiya OS, Punia RC. Change in storage enzymes activities in natural and accelerated aged seed of wheat (Triticum aestivum). Indian J Agric Sci 2011; 81: 1037-1040.

Yin G, Xin X, Song C, Chen X, Zhang J, Wu $\mathrm{S}$ et al. Activity levels and expression of antioxidant enzymes in the ascorbate-glutathione cycle in artificially aged rice seed. Plant Physiol Biochem 2014; 80: 1-9.

Nasr N, Carapetian J, Heidari R, Rezaei SA,
Abbaspour N, Darvishzadeh R et al. The effect of aluminium on enzyme activities in two wheat cultivars. African J Biotechnol 2011; 10: 33543364.

Scialabba A, Bellani LM, Dell'Aquila A. Effects of ageing on peroxidase activity and localization in radish (Raphanus sativus L.) seeds. Eur $J$ Histochem 2002; : 351-358.

Pallavi M, Kumar SS, Dangi KS, Reddy A V. Effect of Seed Ageing on Physiological, Biochemical and Yield Attributes in Sunflower (Helianthus annuus L.) cv. Morden. SEED Res DELHI- 2003; 31: 161-168.

Siadat SA, Moosavi A, Zadeh MS. Effects of seed priming on antioxidant activity and germination characteristics of maize seeds under different ageing treatment. Res J Seed Sci 2012; 5: 5162.

Kaushik SK, Rahul K. Effect of polymer film coating, fungicide and storage treatment on vigour and viability of maize seeds. Trends Biosci 2014; 7: 2361-2364.

\section{How to cite this article:}

Ravindra Singh Bhadauria, Arun Kumar Chaurasia, Mohammad Haris Siddiqui, Khalid Habib and Soban Ahmad Faridi 2019. Enzymatic Activity of Hybrid Maize Cultivar Seeds Stored in Different Packaging Materials under Ambient Conditions with Different Seed Coatings. Int.J.Curr.Microbiol.App.Sci. 8(09): 2393-2404. doi: https://doi.org/10.20546/ijcmas.2019.809.277 